\title{
DISIPLIN BELAJAR PADA PEMBELAJARAN MATA KULIAH PRAKTIK PROGRAM STUDI PENDIDIKAN KESEJAHTERAAN KELUARGA JURUSAN IKK FPP UNP
}

\author{
Fatimah Nuraini $^{{ }^{*}}$, Ernawati ${ }^{2 *}$ \\ Program Studi Pendidikan Kesejahteraan Keluarga Jurusan Ilmu Kesejahteraan Keluarga \\ Fakultas Pariwisata dan Perhotelan \\ Universitas Negeri Padang \\ Jl. Prof. Dr. Hamta, Air Tawar Padang, Kel. Air Tawar Barat, Kec. Padang Utara, Kota Padang, Kode Pos 25171 \\ Sumatera Barat. Indonesia \\ Email: fatimahaini94@gmail.com
}

\begin{abstract}
Abstrak
Penelitian dilatarbelakangi oleh kurangnya disiplin belajar pada pembelajaran mata kuliah praktik Program Studi Pendidikan Kesejahteraan Keluarga Keahlian Tata Busana yang dapat berdampak pada proses pembelajaran. Tujuan penelitian ini melihat kedisiplinan mahasiswa Program Studi Pendidikan Kesejahteraan Keluarga Keahlian Tata Busana dari aspek:1) ketepatan waktu, 2 kesiapan bertindak. Metodologi penelitian yang digunakan adalah deskriptif kuantitatif. Populasi berjumlah 144 orang dan sampel berjumlah 72 orang menggunakan teknik pengambilan sampel yaitu istematik random sampling. Teknik pengumpulan data menggunakan kusioner. Teknik analisis data menggunakan spss 16. Hasil penelitian menunjukkan bahwa disiplin belajar pada pembelajaran praktik dalam aspek 1) ketepatan waktu cukup (50\%), 2) kesiapan bertindak cukup (58\%). Kesimpulannya bahwa mahasiswa sebagian hadir tepat waktu, sebagian menyelesaikan tugas praktik tepat waktu dan sebagian mahasiswa yang mempersiapkan perlengkapan belajar. Saran penelitian ini adalah sebaiknya adanya kerjasama antara mahasiswa dan dosen untuk meningkatkan disiplin belajar pada pembelajaran praktik.
\end{abstract}

Kata Kunci: disiplin, pembelajaran, praktik.

\begin{abstract}
This research is motivated by the lack of discipline in learning practical subjects PKK Study Program in The IKK Departemenet of FPP UNP which can have an impact on the Fashion Skill PKK Study Program from aspects: 1) timeliness, 2) readliness to act. The research methodology used is descriptive quantitative. The population is 144 people and a sample of 72 is determined based on the sampling technique that is systematic random rampling. The technique of collecting data uses a questionnaire. Data analysis techniques uses spss 16. The results of the study show that discipline in practical learning in terms of aspects 1) timeliness is enough (50\%), 2) readliness to act is enough (58\%). The conclusion is that some of the students attend on time, some students complete assignments on time, some who complete the assignment on time, some students prepare learning equipment. The research suggestion is that there should be collaboration between lectures and students so that the discipline of learning in practical learning can be improved.
\end{abstract}

Keywords: discipline, learning, practice.

\section{PENDAHULUAN}

UU No. 23 tahun 2003 mengatakan pendidikan adalah usaha yang dilakukan secara sadar dan terencana untuk mewujudkan susasana belajar dan proses pembelajaran agar peserta didik secara aktif mengembangkan potensi dirinya untuk memiliki kekuatan spiritual keagamaan, membangun kepribadian, pengendalian diri, kecerdasan, akhlak mulia serta keterampilan yang diperlukan dirinya, masyarakat, bangsa dan negara. Melaksanakan pendidkan tersebut, maka Universitas Negeri Padang (UNP) memiliki beberapa jurusan salah satunya Jurusan Ilmu Kesejahteraan Keluarga (IKK). Jurusan IKK menghasilkan lulusan pendidikan di bidang praktik atau skill, salah satunya Prodi Pendidikan Kesejahteraan Keluarga (PKK) Keahlian Tata Busana. Melaksanakan tujuan pendidikan di Prodi PKK Keahlian Tata Busana dapat terlaksana dengan adanya 
proses pembelajaran praktik akan dapat terlaksana dengan baik jika kedisiplinan di dalam proses pembelajaran. Pembelajaran adalah suatu proses yang terjadi antara peserta didik dengan pendidik. Interaksi antara dua belah pihak adalah peserta didik dan pendidik. Di mana peserta didik sebagai warga belajar dan pendidik sebagai sumber belajar.

Pada penelitian ini yang menjadi peserta didiknya yaitu mahasiswa Jurusan Ilmu Kesejahteraan Keluaraga (IKK) Prodi Pendidikan Kesejahteraan Keluarga (PKK) Keahlian Tata Busana. Hal ini berarti yang belajar adalah mahasiswa yang mengikuti kuliah praktik di Prodi PKK Keahlian Tata Busana sedangkan penelitian ini yang dikatakan pendidik adalah dosen Jurusan IKK Prodi PKK Keahlian Tata Busana.

Kedisiplinan harus dimiliki dalam sebuah proses merupakan suautu sikap yang tercipta pada diri seseorang dalam mematuhi segala peraturan dan tata tertib belajar secara teratur. Bentuk disiplin dalam pembelajaran dapat dilihat pada saat sebelum proses pembelajaran, sedang berjalan maupun setelah proses pembelajaran dilakukan oleh pendidik dan peserta didik. Kedisiplinan terbagi menjadi dua yaitu dari ketepatan waktu dan kesiapan. Segi ketepatan waktu adalah kesadaran akan tepat waktu hadir, mengerjakan tugas dan mengumpulkan tugas. Hal tersebut dilihat dari kehadiran mahasiswa datang, pulang dan menyelesaikan tugaspraktik. Mahasiswa Pendidikan Kesejahteraan Keluarga (PKK) Keahlian Tata Busana yang terlambat menghadiri pembelajaran praktik, hal ini menyebabkan mereka terlambat mengikuti pembelajaran pada awal peruliahan. Ketepatan waktu pada mahasiswa Prodi PKK Keahlian Tata Busana didapatkan dari wawancara yang dilakukan pada bulan Februari dan Mei 2018 secara berkala yanng berjumlah 15 orang yang telah mewakili angkatan 2016 dan 2017. Berdasarkan hasil wawancara kepada15 orang mahasiswa tersebut rata-rata menjawab untuk datang ke kampus mereka tidak tepat waktu.

Selain ketepatan waktu hadir dalam pembelajaran juga dilihat ketepatan waktu mengerjakan tugas-tugas praktik serta mengumpulkan tugas-tugas tersebut. Tugas-tugas tersebut diberikan oleh dosen yang bersangkutan, dan tugas tersebut akan diberi nilai. Hal ini tercantum dalam kontrak perkuliahan antara dosen dan mahasiswa point 4 yang menyatakan bahwa mahasiswa wajib mengerjakan tugas yang diberikan kepada dosen karena tugas akan diberi nilai. Maka mahasiswa wajib mengerjakan tugas dan mengumpulkannya tepat waktu. Sedangkan dosen mengumpulkan sesuai dengan jadwal yang telah disepakati sebelumnya.

Disiplin menyangkut akan perilaku disiplin yang sangat terkait dengan penggunaan waktu dan jenis kegitan, baik bekerja, beribadah, beristirahat maupun kegiatan lainnya. Moenir (2010:96) mengatakan bahwa indikator-indikator yang dpaat digunakan untuk mengukur tingkat disiplin yaitu 1) tepat waktu dalam belajar yang mencakup datang dan pulang tepat waktu, 2) tidak meninggalkan kelas, 3) menyelesaikan tugas sesuai waktu yang telah ditetapkan. Sedangkan kedisiplinan dalam kesiapan bertindak yang terjadi adalah tidak mempersiapkan perlengkapan belajar. Sehingga hal itu dapat berdampak pada proses pembelajaran. Kesiapan adalah kesediaan untuk memberi response atau beraksi yang terdiri dari mental dan material.

Kesiapan mental ditandai dengan pengetahuan. Sedangkan kesiapan material diperlukan sebelum perkuliahan dimulai yang meliputi (1) alat tulis untuk perkuliahan; (2)kertas atau buku catatan kuliah;(3) alat-alat pratikum;(4) alat-alat lain yang berhubungan dengan mata kuliah tertentu sesuai dengan kebutuhannya. Berdasarkan rumusan masalah yang diatas, maka tujuan penelitian ini adalah untuk mendapat gambaran mengenai disiplin disiplin belajar pada pembelajaran mata kuliah praktik Prodi Pendiikan Kesejahteraan Keluarga Keahlian Tata Busana Jurusan Ilmu Kesejahteraan Keluarga Fakultas Pariwisata dan Perhotelan Universitas Negeri Padang yang dilihat dari 2 indikator yaitu : 1) ketepatan waktu dan 2) kesiapan bertindak.

\section{KAJIAN TEORI}

Disiplin adalah suatu keadaan tertib ketika orang tunduk untuk tergabbung dalam suatu sistem tunduk pada peraturan-peraturan yang ada dengan senang hati menjalaninya (Mulyasa, 2008:191). Kedisiplinan dapat dilihat bentuknya dari segi kesadaran akan waktu dan kesiapan bertindak Prayitno (2011:152) mengatakan bahwa kualitas kedisiplinan itu terletak pada hal (1) ketepatan waktu, (2) kesiapan bertindak. Kedisiplinan dilaksankan dalam proses pembelajaran. Nana (2004:28) mengatakan bahwa pembelajaran adalah setiap upaya yang sistematik dan sengaja untuk menciptakan interaksi antara dua pihak, yaitu antara peserta didik dan pendidikan yang melakukan kegiatan membelajarkan.

Sukarti (2014:205) peserta didik adalah orang atau individu yang mendapatkan layanan pendidikan sesuai dengan bakat, minat dan kemampuannya agar tumbuh 


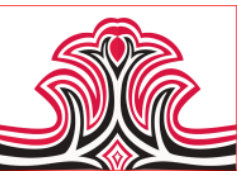

dan berkembang dengan baik serta mempunyai kepuasan dalam menerima pelajaran yang diberikan pendidiknya. Kemudian yang dikatakan pendidik menurut UU RI No. 20 Tahun 2003 tentang Sisdiknas pasal 1 menyebutkan pendidik adalah tenaga kependidikan yang berkualifikasi sebagai guru, dosen, konselor, pamong belajar, widyaiswara, tutor, instruktur, fasilitator dan sebutan lain yang sesuai dengan kekhususan, serta berpartisipasi dala menyelenggarakan pendidikan.

Pembelajaran menyangkut tentang belajar dan mengajar di suatu kelas. Belajar menurut Nana (2011:28) bahwa belajar merupakan suatu proses yang ditandai dengan adanya perubahan pada seseorang. W. H. Buston dalam Suardi (2018:9) mengatakan bahwa belajar sebagai suatu perubahan tingkah laku pada diri individu dan individu dengan lingkungannya. Jadi belajar adalah suattu proses perubahan pada individuindividu dari yang tidak tahu menjadi tahu dari segi pengetahuan, keterampilan maupun sikap agar tujuan tercapai. Gulo (2002:8) mengajar merupakan usaha untuk menciptakan sistem lingkungan yang memungkinkan terjadinya proses belajar itu secara optimal. Smith dalam Sanjaya (2006:65) bahwa mengajar adalah menanamkan pengetahuan dan keterampilan. Jadi mengajar adalah suatu usaha menciptakan lingkungan yang memungkinkan terjadinya proses belajar pada peserta didik secara otimal. Pembelajaran yang dilakukan yaitu pembelajaran mata kuliah praktik dilaksanakan di laboratorium atau workshop.

Sudira (2015:91) sarana praktik adalah segala sesuatu yang dipakai sebagai alat dalam mencapai maksud atau tujuan pembelajaran (pratikum), hal ini berarti tempat dilaksanakannya pratiku (workshop), peralatan dan bahan yang digunakan dalam melaksanakan pratikum yang ada di laboratorium.

Jadi pembelajaran praktik untuk mencapai maksud pembelajaran dibutuhkan sarana yaitu tempat dilaksanakannya praktik yaitu workshop. Terjadinya proses pembelajaran mata kuliah praktik akan dapat terlaksana dengan baik jika ada kedisiplinan dalam proses pembelajaran. Mulyasa (2008:191) disiplin adalah suatu keadaan tertib, ketika orang-oramg yang tergabung dalam suatu sistem tunduk

\section{METODE PENELITIAN}

Penelitian ini, peneliti ingin melihat objek atau segala yang terjadi bagaimana adanya, oleh sebab itu penelitian ini deskriptif kuantitatif. Populasi dalam penelitian ini adalah mahasiswa Program Studi Pendidikan Kesejahteraan Keluarga Keahlian Tata
Gorga Jurnal Seni Rupa

Volume 08 Nomor 01 Januari-Juni 2019

p-ISSN: 2301-5942 | e-ISSN: 2580-2380

Busana yang berjumlah 144 orang. Pengambilan sampel dilakukan dengan metode sistmatic random sampling, sehingga di dapat sampel dengan jumlah 72 orang. Teknik pengumpulan sampel adalah kusioner dengan menggunakan skala likert. Alat pengumpulan data yang digunakan adalah daftar pernyataan dan analisis data menggunakan spss 16.

\section{HASIL DAN PEMBAHASAN \\ 1.Hasil}

Penelitian yang dilakukan dapat diketahui dari hasil kusioner yang telah disebarkan kepada mahasiswa Program Studi pendidikan Kesejahteraan Keluarga (PKK) Keahlian Tata Busana sebanyak 72 orang. Variabel dalam penelitian ini yaitu melihat disiplin belajar pada pembelajaran mata kuliah praktik Prodi PKK Keahlian Tata Busana Juruusan Ilmu Kesejahteraan Keluarga Fakultas Pariwisata dan perhotelan Universitas Negeri Padang. Adapun gambaran disiplin belajar pada pembelajaran dari dua aspek yaitu ketepatan waktu dan kesiapan bertindak.

1) Menggambarkan disiplin belajar pada pembelajaran mata kuliah praktik dalam ketepatan waktu. Berdasarkan data angket atau kusioner yang disebar pada indikator disiplin belajar pada pembelajaran mata kuliah praktik dalam ketepatan waktu terdapat 12 item pernyataan. Berikut hasil penelitian mengenai disiplin belajar pada pembelajaran mata kuliah praktik dalam ketepatan waktu:

Tabel 1. Tabulasi Rentangan Skor Ketepatan Waktu Dalam Pembelajaran Praktik

\begin{tabular}{|l|l|r|r|}
\hline \multicolumn{1}{|c|}{ Rentangan Skor } & \multicolumn{1}{|c|}{ Kategori } & F & \multicolumn{1}{c|}{ (\%) } \\
\hline $90-100 \%$ & Sangat Baik & 1 & $1 \%$ \\
\hline $80-89 \%$ & Baik & 12 & $17 \%$ \\
\hline $65-79 \%$ & Cukup & 36 & $50 \%$ \\
\hline $55-64 \%$ & Kurang & 20 & $28 \%$ \\
\hline $0-54 \%$ & Tidak Baik & 3 & $4 \%$ \\
\hline \multicolumn{2}{|r|}{ Jumlah } & 72 & $100 \%$ \\
\hline
\end{tabular}

Tabel diatas menunjujan bahwa hasil dari 72 orang mahasiswa hanya 1 orang $(1 \%)$ berada pada kategori sangat baik, 12 orang mahasiswa $(17 \%)$ berada pada kategori baik, 36 orang mahasiswa (50\%) berada pada kategori cukup, 20 orang mahasiswa (28\%) berada pada ketgori kurang baik dan 3 orang mahasiswa (4\%) berada pada kategori tidak baik. Untuk lebih jelasnya mengenai disiplin belajar pada pembelajaran mata kuliah praktik dalam ketepatan waktu bisa dilihat pada histogram berikut: 

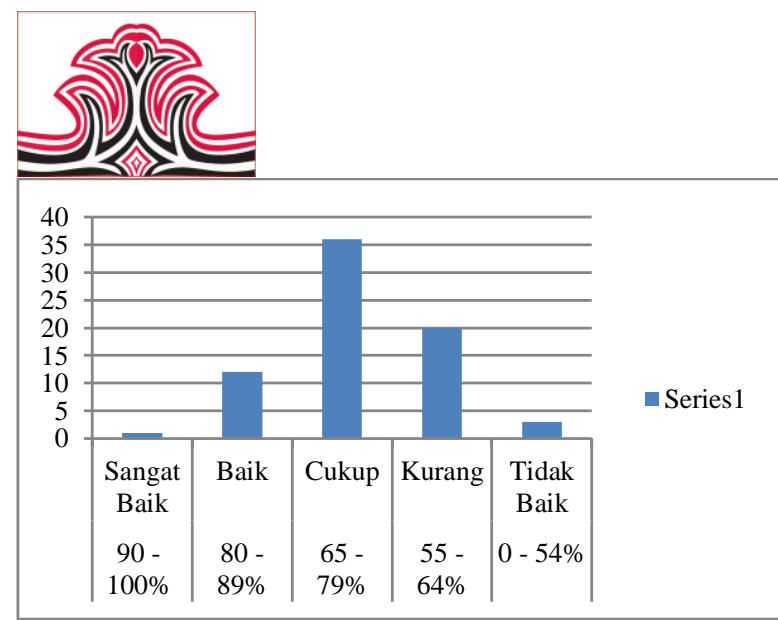

Gambar 1. Histogram Ketepatan Waktu Dalam Pembelajaran Praktik

Dari histogram di atas dapat diketahui bahwa gambaran disiplin belajar pada pembelajaran mata kuliah praktik dilihat dari aspek ketepatan waktu yaitu ketepatan waktu datang dan pulang dalam pembelajaran praktik. makas skor rata-rata pencapaian responden berada pada kategori cukup, yaitu sebanyak 36 orang dengan hasil persentase $50 \%$. Jadi dapat disimpulkan disiplin belajat dalam ketepatan waktu menunjukkan disiplin belajar yang cukup.

2) Menggambarkan disiplin belajar pada pembelajaran mata kuliah praktik dalam kesiapan bertindak. Berdasarkan data angket atau kusioner yang disebar pada indikator disiplin belajar pada pembelajaran mata kuliah praktik dalam kesiapan bertindak terdapat 7 item pernyataan. Berikut hasil penelitian mengenai disiplin belajar pada pembelajaran mata kuliah praktik dalam kesiapan bertindak.

Tabel 2. Tabulasi Rentangan Skor Kesiapan Bertindak Dalam Pembelajaran Praktik

\begin{tabular}{|c|c|c|c|}
\hline Rentangan Skor & Kategori & $\mathrm{F}$ & $\mathrm{f}(\%)$ \\
\hline $90-100 \%$ & Sangat Baik & 3 & $4 \%$ \\
\hline $80-89 \%$ & Baik & 14 & $19 \%$ \\
\hline $65-79 \%$ & Cukup & 42 & $58 \%$ \\
\hline $55-64 \%$ & Kurang & 12 & $17 \%$ \\
\hline $0-54 \%$ & Tidak Baik & 1 & $1 \%$ \\
\hline \multicolumn{2}{|c|}{ Jumlah } & 72 & $100 \%$ \\
\hline
\end{tabular}

Tabel diatas menunjukkan bahwa 72 orang mahasiswa hanya 3 orang (4\%) berada pada kategori sangat baik, 14 orang mahasiswa (19\%) berada pada kategori baik, 42 orang mahasiswa (58\%) berada pada kategori cukup, 12 orang mahasiswa (17\%) berada pada kategori kurang dan 1 orang mahasiswa (1\%) berada pada kategori tidak baik. Untuk lebih jelasnya mengenai disiplin belajar pada pembelajaran mata kuliah praktik dalam kesiapan bertindak bisa dilihat pada histogram berikut:
Gorga Jurnal Seni Rupa

Volume 08 Nomor 01 Januari-Juni 2019

p-ISSN: 2301-5942 | e-ISSN: 2580-2380

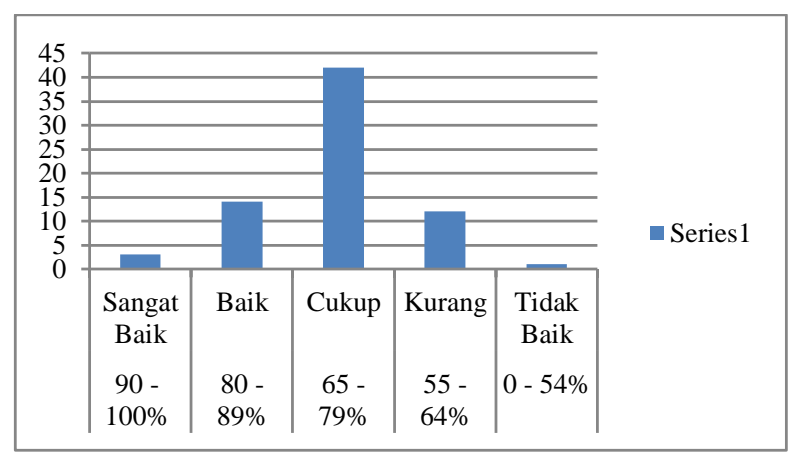

Gambar 2. Histogram Kesiapan Bertindak Dalam Pembelajaran Praktik

Dari histogram di atas dapat diketahui bahwa skor rata-rata pencapaian responden pada kesiapan bertindak berada pada kategori cukup yaitu sebanyak 42 orang dengan heasil persentase $58 \%$. Jadi dapat disimpulkan disiplin belajar pada pembelajaran mata kuliah praktik dalam kesiapan bertindakmenunjukkan disiplin belajar yang cukup.

\section{Pembahasan}

Hasil penelitian ini akan mendeskripsikan hasil pengolahan data tntang disiplin belajar pada pembelajaran mata kuliah praktik Program Studi Pendidikan Kesejahteraan Keluarga (PKK) Keahlian Tata Busana dengan 2 indikator yaitu (1) Ketepatan Waktu, (2) Kesiapan Bertindak. Pada bagian ini akan dikemukakan pembahasan hasil penelitian tentang disiplin belajar pada pembelajaran mata kuliah praktik Prodi PKK Keahlian Tata Busana. Untuk lebih jelasnya akan dibahas satu persatu.

\section{1). Disiplin Belajar Pada Pembelajaran Mata Kuliah Praktik Dalam Ketepatan Waktu}

Berdasarkan hasil penelitian disiplin belajar pada pembelajaran mata kuliah praktik dalam ketepatan waktu digolongkan pada kategori cukup dengan hasil persentase $50 \%$. Kategori cukup tersebut menunjukkan bahwa mahasiswa Pendidikan Kesejahteraan Keluarga (PKK) Keahlian Tata sebagian mahasiswa PKK Keahlian Tata Busana hadir tepat waktu. Hal ini dapat dilihat pada kehadiran mereka yang datang tidak sesuai jadwal perkuliahan praktik dan pulang yang tidak sesuai jadwal.

Ketepatan waktu menurut Moenir (2010:96) indikator yang digunakan untuk mengukur tingkat disiplin belajar yaitu (1) tepat waktu dalam belajar, mencakup datang dan pulang tepat waktu, mulai dan selesai belajar tepat waktu. Menurut hasil penelitian, ketepatan waktu mahasiswa Pendidikan Kesejahteraan Keluarga Keahlian Tata Busana masih kadang-kadang tepat waktu untuk hadir pada pembelajaran praktik. Hal ini menunjukkan hanya sebagian mahasiswa yang 
hadir tepat waktu pada pembelajaran praktik, (2) menyelesaikan tugas sesuai waktu yang ditetapkan.

Dalam hal menyelesaikan tugas, ada mahasiswa Pendidikan Kesejahteraan Keluarga Keahlian Tata Busana tepat waktu menyelesaikan tugas praktik dan ada pula yang tidak tepat waktu. Hal ini dilihat dari mahasiswa yang terlambat mengumpulkan tugas praktik. Hal ini disebabkan oleh kebiasaan mahasiswa yang tidak mengerjakan tugasnya dengan baik dan tidak memanfaatkan waktu untuk menyelesaikan tugas. Ditunjukkan dengan hasil penelitian bahwa mahasiswa tidak mengerjakan tugas ketika diluar kelas. Sehingga waktu yang ada tidak termanfaatkan dengan baik.

Ketepatan waktu yang diterapkan mahasiswa dalam membentuk pola kebiasaan akan menjadi faktor pendukung bagi tiap-tiap mahasiswa dalam mewujudkan keberhasilan belajar. Mahasiswa yang yang berdisiplin tinggi akan selalu tepat waktu. Menurut Alex dalam Slameto (2010) mengemukakan bahwa adanya keterlambatan seseorang dalam melaksanakan kegiatan di luar kebiasaan dapat menunjukkan indikasi disiplin belajar yang disebabkan karena kemalasan, bila kemalasan seseorang berlarut-larut akan mengakibatkan disiplin belajarnya menurun. Namun sebaliknya, jika kemalasan seseorang tidak dibiarkan akan membuatnya menjadi kebiasaan yang menyebabkan disiplin seseorang meningkat dengan baik.

Berdasarkan penjelasan diatas bahwa ketepatan waktu dalam pembelajaran mata kuliah praktik adalah sikap seorang pengajar dalam melaksanakan tugasnya sesuai dengan waktu dan aturan yang telah ditentukan sehingga pekerjaan terlaksanakan dengan baik dan benar. Menurut Gie dalam Slameto (2010) menyatakan bahwa bahwa teknik penggunaan waktu belajar yang efektif dan efisien yang dapat membantu menemukan kebiasaan belajar yang baik akan meningkatkan hasil belajar yang baik yang ditunjukkan dengan sikap adanya persiapan belajar, yaitu dapat menggunajang waktu belajar dengan efektif dan efisien apabila sebelumnya sudah ada persiapan diri dan persiapan sarana untuk belajar. Dapat disimpulkan bahwa persiapan belajar dari segi waktu merupakan satu bentuk kedisiplinan dalam belajar. Demikian adanya kedisiplinan dari segi waktu akan meningkatkan keefektifan dan peningkatan hasil belajar.

\section{2). Disiplin Belajar Pada Pembelajaran Mata Kuliah Praktik Dalam Kesiapan Bertindak}

Berdasarkan hasil penelitian terhadap indikator disiplin belajar pada pembelajaran mata kuliah praktik dalam kesiapan berada pada karegori cukup dengan hasil persentase sebanyak 58\%. Hal ini berarti sebagian mahasiswa Pendidikan Kesejahteraan Keluarga Keahlian Tata Busana mempersiapkan segala sesuatu dalam pembelajaran praktik.

Kesiapan bertindak terdiri dari dua indikator yaitu dari segi pengetahuan dan material (fisik). Seperti ia menyiapkan pegetahuannya dengan cara mempelajari jobsheet yang telah diberikan sebelumnya dan mempersiapkan segala peralatan dan bahan yang akan digunakan untuk pembelajaran praktik. Berdasarkan hasil penelitian mahasiswa Pendidikan Kesejahteraan Keluarga (PKK) Keahlian Tata Busana kadang-kadang mempelajari job sheet sebelum pembelajaran praktik dilaksanakan. Sedangkan untuk kesiapan material yaitu mempersiapkan perlengkapan pembelajaran sebelum pembelajaran dilaksanakan. Berdasarkan hasil penelitian mahasiswa PKK Keahlian Tata Busana kadang-kadang untuk mempersiapkan perlengkapan untuk pembelajaran praktik, seperti lupa untuk membawa pakaian praktik.

Dalyono (1997:52) mengatakan bahwa setiap orang yang hendak melakukan kegiatan belajar harus memiliki kesiapan yakni dengan kemampuan yang cukup baik fisik, mental maupun perlengkapan belajar. Adapun kemampuan yang cukup dari mental dalam pembelajaran yakni merupakan pengetahuan mengenai belajar. Hal yang dipersiapkan mengenai materi pembelajaran seperti jobsheet yang dipelajari sebelum pembelajaran praktik dilaksanakan, sehingga pembelajaran menjadi lancar dan efektif.

\section{KESIMPULA DAN SARAN}

\section{Kesimpulan}

Berdasarkan hasil penelitian yang telah diuraikan, maka dapat ditarik kesinpulan sebagai berikut:

Disiplin belajar pada pembelajaran mata kuliah praktik Program Studi Pendidikan Kesejahteraan Keluarga Keahlian Tata Busana Jurusan Ilmu Kesejahteraan Keluarga Fakultas Pariwisata dan Perhotelan Universitas Negeri Padang dalam ketepatan waktu berada pada kategori cukup yaitu sebanyak 50\%. Hal ini berarti sebagian mahasiswa PKK Keahlian Tata Busana hadir tepat waktu dan sebagian pula yang menyelesaikan tugas praktik tepat waktu.

Disiplin belajar pada pembelajaran mata kuliah praktik Program Studi Pendidikan Kesejahteraan Keluarga Fakultas Pariwisata dan Perhotelan 
Universitas Negeri Padang dalam kesiapan bertindak berada pada kategori cukup yaitu sebanyak 58\%. Hal ini berarti sebagian yang mempersiapkan perlengkapan belajar untuk pembelajaran praktik.

\section{Saran}

Berdasarkan hasil penelitian yang telah disimpulkan tersebut, maka peneliti memberikan saran sebagai berikut:

Mahasiswa diharapkan untuk memperhatikan ketepatan waktu datang, pulang dan mengumpulkan tugas sesuai waktu sesuai jadwal yang telah disepakati pada pembelajaran mata kuliah praktik di Jurusan Ilmu Kesejahteraan Keluarga Fakultas Pariwisata Dan Perhotelan Universitas Negeri Padang.

Mahasiswa diharapkan untuk mempersiapkan perlengkapan belajar sebelum pembelajaran mata kuliah praktik dilaksanakan di Jurusan Ilmu Kesejahteraan Keluarga Fakultas Pariwisata Dan Perhotelan Universitas Negeri Padang.

Dosen diharapkan dapat mengingatkan mahasiswa untuk memperhatikan hadir tepat waktu dan menyelesaikan tugas praktik tepat waku pada pembelajaran mata kuliah praktik Jurusan Ilmu Kesejahteraan Keluarga Fakultas Pariwisata Dan Perhotelan Universitas Negeri Padang.

Dosen diharapkan dapat mengingatkan mahasiswa untuk mempersiapkan perlengkapan belajar sebelum pembelajaran praktik dilaksanakan di Jurusan Ilmu Kesejahteraan Keluarga Fakultas Pariwisata Dan Perhotelan Universitas Negeri Padang.

Bagi Jurusan Ilmu Kesejahteraan Keluarga, diharapkan lebih tegas dalam menegakkan kedisiplinan mahasiswa terutama kepada mahasiswa Prodi Pendidikan Kesejahteraan Keluarga Keahlian Tata Busana Jurusan Ilmu Kesejahteraan Keluarga Fakultas Pariwisata Dan Perhotelan Universitas Negeri Padang.

Bagi peneliti yang ingin melanjutkan penelitian, diharapkan pada peneliti lain agar dapat melihat beberapa faktor lain yang belum diteliti dalam penelitian ini.

\section{DAFTAR RUJUKAN}

Dalyono, M. (1997). Psikologi Pendidikan: Komponen MKDK. Jakarta: Rineka Cipta.
Gorga Jurnal Seni Rupa

Volume 08 Nomor 01 Januari-Juni 2019

p-ISSN: 2301-5942 | e-ISSN: 2580-2380

Gulo, W. (2008). Strategi Belajar Mengajar. Jakarta: Grasindo.

Moenir, A. S. (2010). Manajemen Pelayanan Umum Di Indonesia. Jakarta: Bumi Aksara.

Mulyasa, E. (2008). Implementasi Kurikulum Tingkat Satuan Pendidikan, Kemandirian Guru danKepala Sekolah. Jakarta : Bumi Aksara.

Nana, S. (2004). Dasar-Dasar Proses Belajar Mengajar. Bandung: Sinar Baru Algensindo offset.

(2011b). Dasar-Dasar Proses Belajar Mengajar. Bandung: Sinar Baru Algensindo offset.

Prayitno dan Khaidir, A. (2011). Model Pendidikan Karakter - Cerdas. Padang: UNP Press.

Sanjaya. (2006). Kurikulum Dan Pembelajaran. Jakarta: Kencana.

Slameto. .2010. Belajar dan Faktor-Faktor Yang Mempengaruhinya. Jakarta: Rineka Cipta.

Suardi, M. (2018). Belajar dan Pembelajaran. Yogyakarta: Deepublish.

Sudira, Putu \& Aini Siti Nurul. (2015). Pengaruh Strategi Pembelajaran, Gaya Belajar, Sarana Praktik dan Media Terhadap Hasil Belajar Patiseri SMK SeGerbangkentasusila. Jurnal Pendidikan Vokasi. 5(1).-.

Sukarti. (2014). Manajemen Pendidikan. Bandung : Alfabeta.

Undang-Undang Republik Indonesia Nomor 20 Tahun Tahun 2003 tentang Sistem Pendidikan Nasional. 